Article

\title{
Flammability Characteristics of Surface Fuels in a Longleaf Pine (Pinus palustris Mill.) Woodland
}

\author{
Raien K. Emery and Justin L. Hart *(D) \\ Department of Geography, University of Alabama, Tuscaloosa, AL 35487, USA; rkemery@crimson.ua.edu \\ * Correspondence: hart013@ua.edu; Tel.: +1-205-348-1673
}

Received: 26 June 2020; Accepted: 1 August 2020; Published: 4 August 2020

check for updates

\begin{abstract}
To investigate fuel flammability, we quantified burning characteristics of 21 fuel categories in a longleaf pine (Pinus palustris Mill.) woodland in central Alabama, USA. Litter was burned under controlled laboratory conditions. Flammability characteristics, including resistance to ignition, flaming duration, smoldering duration, maximum flame height, and percent consumption, were measured. The fuels were hierarchically clustered into five groups of similar flammability characteristics that explained $89 \%$ of the variance. Percent consumption and maximum flame height values ranged from $7 \% \pm 1$ standard errors (SE) and $12 \mathrm{~cm} \pm 1 \mathrm{SE}$ for the low flammability group (bark and charcoal), to $86 \% \pm 1 \mathrm{SE}$ and $62 \mathrm{~cm} \pm 3 \mathrm{SE}$ for the high flammability group (bracken fern (Pteridium latiusculum (Desv.) Hieron. ex R.E.Fr. = \{syn: P. aquilinum $\}$ ), grass, and fire-facilitating oak (Quercus spp.) leaves). Results support observed flammability differences between fuel types such as oak and pine (Pinus spp.) litter, and duff, and provide a previously unquantified comparison of surface fuels comprehensive of a longleaf pine community. Further, clustering analysis indicated that plant species that become abundant post-disturbance may help maintain fire-vegetation feedbacks in the absence of pine litter. Understanding flammability characteristics of surface fuels may further inform prescribed fire application in stands where fuels have been altered.
\end{abstract}

Keywords: fire-vegetation feedbacks; fuel bed; laboratory burn; oak (Quercus); prescribed fire

\section{Background}

Forest fires modify plant community composition and structure, which collectively influence fuel loading, composition, and connectivity. In frequent-fire forests, fires facilitate the continued dominance of fire-adapted tree species and maintain pyrophytic ground flora in the understory. Thus, fire-vegetation feedbacks are critical to maintain fire-dependent forest ecosystems. Modifications to fuel conditions, forest composition or structural elements, or fire frequency or severity can alter these feedbacks and result in a transition to a new state [1,2]. A key component in this feedback loop is the flammability of surface fuels. Flammability refers broadly to the capacity of fuels to ignite and combust [3] and is more specifically based on ignitability, sustainability, combustibility, and consumability. These four components relate to the ignition delay, combustion duration, mass loss rate, and percentage of fuel consumed by fire, respectively [3-5]. Alterations in plant community composition will result in a modified fuel bed, which will in turn alter fire behavior and ultimately, fire effects. Therefore, managers of frequent-fire forests are concerned with fuel loading and composition to ensure the application of prescribed fire will result in the desired outcome.

Longleaf pine (Pinus palustris Mill.) stands of the southeastern USA are excellent examples of fire-dependent ecosystems. In these ecosystems, surface fires at short intervals cause shoot mortality of undesirable, fire-intolerant species that may otherwise outcompete longleaf pine advanced reproduction for canopy dominance [6]. Longleaf pine seedlings and saplings often survive these fires because of a dense collection of pine needles surrounding their apical meristem (especially important during the grass stage), 
their relatively thick bark, extensive root network, and propensity to prune lower limbs [7]. Fires also reduce duff and expose bare mineral soil which aids longleaf pine regeneration [8]. Often, longleaf pine forests are managed on a 1-4-year prescribed fire rotation, however, it is not well documented if these fires effectively aid longleaf pine regeneration on sites where fuels have potentially been altered from historical fire-vegetation feedbacks. Shifts in forest composition and structure from fire exclusion, with subsequent increases of mesophytic tree species (shade-tolerant, fire-sensitive species that tend to create cool, damp, and shaded conditions, [9]), alter fuels, fire behavior, and ultimately disrupt processes that maintain persistent pine ecosystems [2]. Catastrophic disturbances also modify fire-vegetation feedbacks through the reduction of canopy-derived fuel and altered conditions near the forest floor.

Understanding fire-vegetation feedbacks in fire-dependent ecosystems is critical for proper management. Although fire-vegetation feedbacks are well documented for longleaf pine stands of the USA Coastal Plain and Sandhills regions [2,6,10-16], less is known about fire regimes of montane longleaf pine ecosystems [17-19]. Further, few studies have incorporated the impact of natural, catastrophic disturbances on surface fuel continuity and composition [20,21], both important constraints on fire intensity [22]. Fire behavior is influenced by wind, topography, and fuel moisture, loading, and composition (senesced leaves, herbs, and woody debris, [23]). Fuel analyses of fire-excluded oak-hickory (Quercus-Carya, [24]) and montane longleaf pine woodlands [25] led researchers to conclude that fire regimes, once historically present within a stand, are unlikely to be possible without stand manipulation. Further, relative abundances of fuel types influence fire severity. For example, Wenk et al. [12] found wiregrass (Aristida stricta Michx.) fuel complexes created less severe fires than those composed of turkey oak (Quercus laevis Walt.). In general, higher fuel loads produce more intense fires, potentially creating lethal soil temperatures and causing plant mortality $[6,11,16]$. Thus, it is important to understand how fire behaves in longleaf pine woodlands where available fuel abundance and composition may be altered by catastrophic disturbance [26].

Initial attempts to understand fire behavior in the field often involve laboratory burns, which elucidate different flammability characteristics of specific forest fuels. Laboratory burns often involve recording simple metrics, such as maximum flame height, flaming duration, and percent consumption, to describe the flammability of an isolated fuel [3]. Quantifying the different flammability characteristics of fuels, particularly percent consumption, which is highly correlated with fire intensity [27] and a critical component in estimating fire behavior, soil heating, and post-fire soil exposure [28], may improve our understanding of the ecological impacts of prescribed fire. Laboratory burns have successfully revealed largely intrageneric flammability differences, excluding [12,29,30]. Previous laboratory burning experiments of fuel relevant to longleaf pine woodlands have focused specifically on either fine woody debris, southeastern USA oak species, pinecones, or pine needles [31-35]. No studies have comprehensively examined multiple types of surface fuels in a forest using the same methods.

Most literature indicates that pine needles are necessary for desirable fire intensity and continuity in longleaf pine ecosystems [14,36]. However, we suspected that longleaf pine stands recovering from natural, catastrophic disturbance, especially disturbances as common as tornadoes in the southeastern USA [37], likely involve fire-vegetation feedbacks that aid longleaf pine regeneration in the absence of pine needles. More specifically, we hypothesized that previously unstudied, herbaceous species characteristic of longleaf pine ecosystems such as bracken fern (Pteridium latiusculum (Desv.) Hier. ex. Fries $=\{$ syn: P. aquilinum $\}$ ), yellow jessamine vine (Gelsemium sempervirens (L.) J.St.-Hil.), Vaccinium spp., or grass (Poacea) share similar flammability characteristics to pine needles. Further, categorizing diverse surface fuels into groups of similar flammability characteristics may provide future studies the opportunity to compare results more readily and feasibly from laboratory burns to fire effects in the field. Another benefit of clustering fuels into similar flammability groups is that managers would only need to measure fuel loadings in these groups to broadly understand surface fuel flammability.

We tested these hypotheses in the following three objectives: (1) quantify flammability characteristics of diverse surface fuels in a longleaf pine woodland using laboratory experiments, (2) classify diverse surface fuels into groups with similar flammability characteristics, and (3) describe the relative abundances 
of fuel types in a longleaf pine woodland as a function woody, leafy, and total fuels. By understanding surface fuel flammability broadly and in the context of what is representative of actual fuel beds, our study identifies flammability of previously unstudied fuels, simplifies the process of sorting fuels into meaningful classes, and assists fire managers in achieving desirable results when applying prescribed fire.

\section{Methods}

\subsection{Study Site}

This study was conducted on the Oakmulgee Ranger District of the Talladega National Forest in central Alabama, USA $\left(32.9278^{\circ} \mathrm{N}, 87.4000^{\circ} \mathrm{W}\right)$. The study site is in the Fall Line Hills, a physiographic transition where marine-deposited sedimentary rock belts of the Coastal Plain meet the steep slopes and ridges characteristic of the Appalachian Highlands [38]. The major strata of the region are the Gordo and Coker formations of the Upper Cretaceous, with deep, moderately well-drained soils characteristic of the Maubila series [39]. Upland soils on our sites are Ultisols, acidic, and sandy clay loam to clay soils on the ridges and upper slopes, with less clay occurring at middle and lower slopes [40]. Elevation varies from 55-183 m above mean sea level.

The region has a humid mesothermal climate, with long hot summers and short mild winters [41]. Across a thirty-year period (1988-2017), average annual temperature of the region was $17^{\circ} \mathrm{C}$, with an average monthly high of $27^{\circ} \mathrm{C}$ in July and an average monthly low of $7^{\circ} \mathrm{C}$ in January [42]. Average annual precipitation from the same period was $1390 \mathrm{~mm}$, with the wettest month, February, averaging $140 \mathrm{~mm}$ of precipitation, and the driest month, October, averaging $75 \mathrm{~mm}$ [42]. The regional growing season spans ca. 200 days from March to November.

As a physiographic transition, the region supports species representative of both the Coastal Plain and the Appalachian Highlands [43]. Beckett and Golden [40] conducted a floristic survey of the study area and concluded the longleaf pine forest community was the most common, especially dominant on upper slopes and south-facing middle slopes maintained with fire. Although not located in the Appalachian Highlands, longleaf pine stands of the Alabama Fall Line Hills resemble montane longleaf pine ecosystems $[17,44]$. These sites are characterized by steep slopes with exposed rocks and thin soils and they support many plant species common in the Appalachian Highlands [45].

Our study site is managed using a 2-4-year prescribed fire rotation. In mature stands on this site, Kleinman et al. [46] reported longleaf pine stems $\geq 5 \mathrm{~cm}$ diameter at breast height (dbh) had the greatest basal area $\left(16.21 \mathrm{~m}^{2} \mathrm{ha}^{-1}\right.$ ), followed by loblolly pine (Pinus taeda L., $2.11 \mathrm{~m}^{2} \mathrm{ha}^{-1}$ ), and less than $1 \mathrm{~m}^{2} \mathrm{ha}^{-1}$ each of southern red oak (Quercus falcata Michx), blackjack oak (Quercus marilandica Muenchh.), and flowering dogwood (Cornus florida L.). In total, Kleinman et al. [46] noted the mature longleaf pine woodland had a total basal area of $21.69 \mathrm{~m}^{2} \mathrm{ha}^{-1}$.

As a region prone to tornadoes, the Oakmulgee Ranger District was struck with an EF3 tornado with winds up to $233 \mathrm{~km} \mathrm{~h}^{-1}$ and a maximum swath width of $1609 \mathrm{~m}$ in April 2011 [47]. To recover economic losses and to reduce the threat of wildfire and pest outbreak, easily accessible affected areas were salvage logged July to November of the same year [48]. In June 2016, 60 permanent 400 $\mathrm{m}^{2}$ (0.04-ha) fixed-radius plots were established to monitor post-disturbance recovery, with 20 plots for each treatment type: mature, wind disturbed, and salvage logged. The plots were selected in close proximity (within $1 \mathrm{~km}^{2}$ and in the same watershed) and to ensure similar site characteristics such as soil type, topographic characteristics, management history, and prescribed fire regime [46,49]. Wind disturbance and salvage logging greatly reduced the basal area of longleaf pine stems $\geq 5 \mathrm{~cm}$ dbh to $0.49 \mathrm{~m}^{2} \mathrm{ha}^{-1}$ on wind-disturbed sites, and to $0.27 \mathrm{~m}^{2} \mathrm{ha}^{-1}$ on and salvage-logged sites [46]. This corresponded to a ca. $97 \%$ basal area reduction in catastrophically disturbed areas.

\subsection{Field Methods}

We sampled during the dormant season in January-February 2017 to target senesced and surface fuels representative of conditions when operational burns occur on the study site, and thus when 
flammability measurements would be the most relevant to understanding fire effects. We randomly selected three permanent plots from each treatment (nine total) to ensure observed flammability characteristics were the result of fuel type, and not differing habitats, which Kane et al. [33] observed impacted the flammability of southeastern USA oak species. Each sample consisted of fuel within three $1 \mathrm{~m} \times 1 \mathrm{~m}$ quadrats ( $3 \mathrm{~m}^{2}$ composited by plot) placed on the ground $12.29 \mathrm{~m}$ from plot center at $0^{\circ}, 120^{\circ}$, and $240^{\circ}$. We placed the bottom left corner of the quadrat $1 \mathrm{~m}$ beyond and tangent to the $400 \mathrm{~m}^{2}$ fixed-radius plots to limit interference with herbaceous monitoring. Within each $1 \mathrm{~m} \times 1 \mathrm{~m}$ quadrat, we collected all non-living aboveground organic material, and living herbaceous plants and vines such as yellow jessamine and muscadine (Vitis rotundifolia Michx.). When present, we collected upper duff (the Oe soil horizon-decomposed plant material where the original structure is still recognizable) and lower duff (the Oa soil horizon-highly decomposed plant material where the original structure is unrecognizable) to bare mineral soil [50]. We collected all fine woody debris (FWD, diameter $<10.0 \mathrm{~cm}$ ). FWD or vines that extended beyond the edges of the quadrat were cut at the edge of the quadrat and pieces beyond the edge were not collected. Wood fragments and bark that originated from coarse woody debris $(C W D$, diameter $\geq 10.0 \mathrm{~cm})$ were not collected. Although live saplings and seedlings would likely be consumed in a prescribed fire, we did not collect them because hardwood foliage had senesced, and we did not expect the fine branches would significantly contribute to surface fuels. Fuel was transported to the laboratory, where it was frozen for $48 \mathrm{~h}$ to ensure no pests or diseases were transported from the field. Freezing for this duration did not visibly damage foliage. Fuel equilibrated to laboratory temperature and moisture conditions. As oven drying is hypothesized to impact flammability characteristics of the fuel [3], we did not oven-dry fuel samples used in flammability analyses.

\subsection{Laboratory Sorting}

\subsubsection{Fine Woody Debris}

Although we were able to sort some fuels to species (e.g., bracken fern and yellow jessamine), we could not sort all fuels in all stages of decay by species with confidence. For accurate field applicability, complete fuel beds were sorted to the finest resolution possible. As a result, fuel was initially sorted into 28 reductive fuel categories, though only 21 fuel categories were abundant enough to undergo flammability analysis (see Tables 1 and 2 for descriptions of fuel categories). FWD was separated into nine categories $(0.00-0.63 \mathrm{~cm}$ hardwood, $0.63-2.54 \mathrm{~cm}$ hardwood, $2.54-9.99 \mathrm{~cm}$ hardwood, $0.00-0.63 \mathrm{~cm}$ pine, $0.63-2.54 \mathrm{~cm}$ pine, $2.54-9.99 \mathrm{~cm}$ pine, wood fragments, bark, and charcoal). Size divisions were based on Brown [51], who created divisions by moisture time-lag classes (where woody debris was expected to dry to an equilibrium moisture content) to improve the resolution of fine fuels sampling. Though CWD was present on our sites, we did not collect CWD for flammability analysis because preparing $15.0 \mathrm{~g}$ subsamples of CWD (as consistent with methods for flammability analysis) would have little translatability to fire behavior in the field, and thus provide little meaningful comparison.

Table 1. Fuel categories excluded from flammability analysis for not reaching a minimum of $90 \mathrm{~g}$.

\begin{tabular}{ccc}
\hline Category & Description & Mass (g) \\
\hline Fire-Impeding Oaks & As defined by [33] & 65.6 \\
Moderate-Burning Oaks & As defined by [33] & 19.6 \\
Herbaceous RS & e.g., berries, flowers & 12.8 \\
Hardwood RS & e.g., samaras, acorns & 7.2 \\
Herbs & Not identified to species & 13.5 \\
Scat & e.g., Odocoileus virginianus Zimmermann & 2.9 \\
Insects & Grasshopper, butterfly wings, and a beetle & 0.9 \\
\hline
\end{tabular}

Notes: Category abbreviations include reproductive structures (RS). 
Table 2. Descriptions, averages, and standard errors (SE) for flammability characteristics of the 21 analyzed fuel categories.

\begin{tabular}{|c|c|c|c|c|c|c|}
\hline Category & Description & RI (s) & MFH (cm) & FD (s) & SD (s) & $\mathrm{C}(\%)$ \\
\hline Bark & $\begin{array}{l}\text { Hardwood and pine; } \\
\text { naturally separated }\end{array}$ & $13 \pm 1$ & $12 \pm 0$ & $33 \pm 3$ & $49 \pm 13$ & $6.1 \pm 1.3$ \\
\hline Charcoal & $\begin{array}{l}\text { Majority of fuel blackened } \\
\text { by previous fire }\end{array}$ & $15 \pm 1$ & $11 \pm 2$ & $75 \pm 24$ & $335 \pm 88$ & $7.3 \pm 0.7$ \\
\hline Lower Duff & Duff $0.5-2.0 \mathrm{~mm}$ & $9 \pm 1$ & $9 \pm 1$ & $163 \pm 12$ & $26 \pm 3$ & $9.1 \pm 1.4$ \\
\hline $0.63-2.54 \mathrm{~cm} \mathrm{HW}$ & $\begin{array}{l}\text { Medium size class of } \\
\text { hardwood FWD }\end{array}$ & $14 \pm 1$ & $25 \pm 3$ & $120 \pm 14$ & $269 \pm 76$ & $22.9 \pm 6.4$ \\
\hline Pine RS & Cones and strobili & $7 \pm 0$ & $20 \pm 2$ & $111 \pm 12$ & $217 \pm 45$ & $27.7 \pm 3.2$ \\
\hline $2.54-9.99 \mathrm{~cm} \mathrm{HW}$ & $\begin{array}{l}\text { Large size class of } \\
\text { hardwood FWD }\end{array}$ & $12 \pm 2$ & $24 \pm 1$ & $146 \pm 62$ & $404 \pm 194$ & $36.0 \pm 18.8$ \\
\hline $0.63-2.54 \mathrm{~cm}$ Pine & $\begin{array}{c}\text { Medium size class of pine } \\
\text { FWD }\end{array}$ & $14 \pm 4$ & $20 \pm 6$ & $127 \pm 27$ & $371 \pm 95$ & $36.9 \pm 12.4$ \\
\hline Wood Fragments & $\begin{array}{l}\text { Unidentifiable wood ca. } 0.5 \\
\times 2.0 \mathrm{~cm}\end{array}$ & $10 \pm 1$ & $13 \pm 2$ & $230 \pm 36$ & $298 \pm 26$ & $37.1 \pm 4.3$ \\
\hline Upper Duff & Duff $2.0-4.0 \mathrm{~mm}$ & $6 \pm 1$ & $29 \pm 3$ & $245 \pm 36$ & $112 \pm 22$ & $46.7 \pm 7.4$ \\
\hline $0.00-0.63 \mathrm{~cm} \mathrm{HW}$ & $\begin{array}{l}\text { Small size class of } \\
\text { hardwood FWD }\end{array}$ & $7 \pm 1$ & $39 \pm 5$ & $140 \pm 23$ & $154 \pm 12$ & $55.1 \pm 10.5$ \\
\hline $2.54-9.99 \mathrm{~cm}$ Pine & $\begin{array}{c}\text { Large size class of pine } \\
\text { FWD }\end{array}$ & $13 \pm 3$ & $28 \pm 2$ & $201 \pm 45$ & $515 \pm 90$ & $62.8 \pm 13.1$ \\
\hline $\begin{array}{c}\text { Yellow Jessamine } \\
\text { Vine }\end{array}$ & $\begin{array}{c}\text { Gelsemium sempervirens (L.) } \\
\text { J.St.-Hil.; vine }\end{array}$ & $5 \pm 0$ & $57 \pm 4$ & $91 \pm 6$ & $226 \pm 28$ & $64.5 \pm 5.6$ \\
\hline $0.00-0.63 \mathrm{~cm}$ Pine & $\begin{array}{l}\text { Small size class of pine } \\
\text { FWD }\end{array}$ & $17 \pm 3$ & $37 \pm 4$ & $160 \pm 37$ & $307 \pm 67$ & $69.2 \pm 4.5$ \\
\hline Oak Fragments & $\begin{array}{l}\text { Leaf fragments of } \\
\text { unidentifiable oak species }\end{array}$ & $5 \pm 1$ & $36 \pm 6$ & $102 \pm 18$ & $226 \pm 57$ & $78.5 \pm 2.7$ \\
\hline Non-oaks & $\begin{array}{l}\text { e.g., Acer rubrum L., Cornus } \\
\text { florida L.; leaves }\end{array}$ & $6 \pm 1$ & $41 \pm 4$ & $89 \pm 14$ & $116 \pm 16$ & $78.9 \pm 3.4$ \\
\hline Bracken Fern & $\begin{array}{l}\text { Pteridium latiusculum } \\
\text { (Desv.) Hier. ex. Fries }\end{array}$ & $6 \pm 1$ & $61 \pm 3$ & $64 \pm 4$ & $47 \pm 9$ & $80.8 \pm 2.3$ \\
\hline Pine Needles & e.g., Pinus palustris Mill. & $2 \pm 1$ & $59 \pm 4$ & $100 \pm 11$ & $45 \pm 9$ & $80.8 \pm 2.3$ \\
\hline Ericaceae & $\begin{array}{l}\text { e.g., Vaccinium arboreum } \\
\text { Marsh.; leaves }\end{array}$ & $5 \pm 1$ & $47 \pm 5$ & $77 \pm 7$ & $123 \pm 6$ & $82.5 \pm 2.5$ \\
\hline $\begin{array}{c}\text { Yellow Jessamine } \\
\text { Leaves }\end{array}$ & $\begin{array}{c}\text { Gelsemium sempervirens (L.) } \\
\text { J.St.-Hil.; leaves }\end{array}$ & $5 \pm 1$ & $53 \pm 4$ & $102 \pm 25$ & $70 \pm 5$ & $85.6 \pm 2.9$ \\
\hline Grass & $\begin{array}{l}\text { e.g., Schizachyrium } \\
\text { scoparium Michx. }\end{array}$ & $3 \pm 0$ & $70 \pm 6$ & $51 \pm 6$ & $56 \pm 12$ & $87.6 \pm 0.9$ \\
\hline $\begin{array}{l}\text { Fire-Facilitating } \\
\text { Oaks }\end{array}$ & As defined by [33]; leaves & $5 \pm 1$ & $54 \pm 3$ & $56 \pm 7$ & $121 \pm 8$ & $89.5 \pm 1.8$ \\
\hline
\end{tabular}

Notes: Flammability characteristics include resistance to ignition (RI), maximum flame height (MFH), flaming duration (FD), smoldering duration (SD), and consumption (C). Other abbreviations include hardwood (HW), fine woody debris (FWD), and reproductive structures (RS).

In addition to size classes, FWD was further separated into hardwood (HW) and pine categories based on pore structure and characteristic decompositional shapes (e.g., pine typically has simple end grain and decomposes in red blocks, hardwood typically has complicated end grain, visible parenchyma and rays, and decomposes in gray strings). FWD that could not be identified as hardwood or pine was sorted into the wood fragment category, typically fitting within a $0.5-2.0 \mathrm{~cm}$ rectangle. Bark was not removed from FWD, thus the bark category consisted only of bark that had naturally separated from woody debris. Collected charcoal was FWD judged to be at least $50 \%$ blackened (externally and internally).

\subsubsection{Leaves}

Fuel was sorted into nine categories of leaves (fire-facilitating oaks, fire-impeding oaks, moderate-burning oaks, oak fragments, non-oaks, pine needles, yellow jessamine, Ericaceae, and grass (Poacea)). We acknowledge that grass represented a large category, but it was difficult to identify grasses beyond family. Based on our prior work in these stands, the most abundant grass species is little bluestem (Schizachyrium scoparium Michx.). Laboratory flammability analysis by Kane et al. [33] 
indicated southeastern USA oak species burn in two distinct groups: fire-facilitating (FF) and fire-impeding (FI) oaks. Thus, when possible we sorted oak leaves as FF or FI by species. FF oaks collected on our plots mainly consisted of turkey oak, southern red oak, and post oak (Quercus stellata Wangenh.). FI oaks collected on our plots mainly consisted of water oak (Quercus nigra L.) and Darlington oak (Quercus hemisphaerica Bartr. ex Willd.). Oak species such as blackjack oak, northern red oak (Quercus rubra L.), white oak (Quercus alba L.), black oak (Quercus velutina Lam.), scarlet oak (Quercus coccinea Muenchh.), and chestnut oak (Quercus montana Willd.) were sorted into the FF category based on similar characteristics of physical leaf traits and habitats observed by Kane et al. [33], and further corroborated by Engber and Varner [27]. The only oak collected in our plots that was not clearly a fire facilitator or impeder was the dwarf post oak (Quercus margaretta Ashe ex. Small), which was sorted into the moderate-burning (MB) oak category. Leaves that were identified as oaks but were unable to be identified to species were sorted into the oak fragment category.

Non-oak leaves were not all identified to species, but notable examples included red maple (Acer rubrum L.), flowering dogwood, black gum (Nyssa sylvatica Marsh.), American beech (Fagus grandifolia Ehrh.), and muscadine. According to previous tree species inventories [45] and personal observation, we suspected the contributions of loblolly pine or shortleaf pine (Pinus echinata Mill.) needles would be negligible compared to longleaf pine, thus pine needles were not separated by species even though pine species have been shown to burn differently [35].

Yellow jessamine leaves were expected to burn differently than the woody vine, so they were separated from the vine for flammability analysis. The Ericaceae category was mostly composed of farkleberry (Vaccinium arboreum Marsh.) and deer berry (Vaccinium stamineum L.), though was more loosely named to account for other species with similar leaf thickness, size, or shape, such as Elliott's blueberry (Vaccinium elliottii Chapm.), hillside blueberry (Vaccinium pallidum Aiton), and dwarf huckleberry (Gaylussacia dumosa (Andr.) Torr. and A. Gray, [45]). As previously stated, grass was not identified beyond family, but from our prior work we know that the most abundant species is little bluestem and that corresponds with the International Vegetation Classification for the area [52].

\subsubsection{Reproductive Structures (RS)}

Fuel was sorted into three categories of reproductive structures (pine, herbaceous, and hardwood). Pine RS included all species of pinecones and strobili. Herbaceous RS were mainly composed of Ericaceae berries, pods, and flowers, most of which were sorted by size in upper duff. Hardwood RS were mainly composed of maple (Acer spp.) samaras and oak acorns.

\subsubsection{Other}

The remaining seven fuel categories included yellow jessamine vines (with leaves removed), bracken fern, herbaceous plants (not identified to species), scat, insects, upper duff, and lower duff. The upper duff category consisted of all duff material that could be shaken through a $4.0 \mathrm{~mm}$ mesh, but not through a $2.0 \mathrm{~mm}$ mesh. The lower duff category consisted of all remaining organic material, with any collected soil removed by a $0.5 \mathrm{~mm}$ sieve. Each of the 28 categories was individually weighed by plot to the nearest $0.1 \mathrm{~g}$. Category sums were calculated by treatment and across all treatments.

\subsection{Laboratory Flammability Analysis}

Our laboratory flammability method was adapted from $[13,22,33,53]$ to accommodate the diverse fuel categories representative of the longleaf pine plant community. A central challenge was to develop a method that would consistently ignite the wide range of fuel types we investigated. Six $15.0 \mathrm{~g}$ subsamples were prepared for each fuel category, though often only five were necessary. The extra subsample was burned in the event of an outlier, thus the minimum weight necessary for each category to undergo flammability analysis was $90.0 \mathrm{~g}$ [22]. Seven categories (FI oaks, MB oaks, herbaceous RS, hardwood RS, herbaceous plants, scat, and insects) did not meet the $90.0 \mathrm{~g}$ minimum, were excluded from further analysis, and assumed to have negligible effect on fire behavior (Table 1). The $15.0 \mathrm{~g}$ 
subsamples were prepared with a combination of fuel from each treatment to minimize potential treatment effects on flammability. We acknowledge that by standardizing the fuel beds for burning produces, we burned some fuels in conditions that do not exist in the field. For example, some vertically oriented fuels (e.g., grass) were burned horizontally and some fuels were burned at a bulk density much greater than they typically occur in the field.

Subsamples were ignited on a $2 \mathrm{~cm}$ raised rack over a $35 \mathrm{~cm} \times 35 \mathrm{~cm}$ grid of xylene-soaked cotton strings, and while the area covered by each fuel was allowed to vary, unpacked fuel bed depths were kept constant at $1 \mathrm{~cm}$ for all categories except lower and upper duff (which were spread thinly) and FWD $>1 \mathrm{~cm}$ diameter (0.63-2.54 and 2.54-9.99 cm HW and pine (Figure 1)). Fuel bed depth is an important driver of flammability characteristics [33], thus we attempted to keep fuel bed depth constant to ensure observed flammability differences were the result of the fuels and not of fuel bed depth. Additionally, we used a fuel bed depth of $1 \mathrm{~cm}$ because fuel categories that covered the maximum grid area $(35 \mathrm{~cm} \times 35 \mathrm{~cm})$ had non-compacted fuel bed depths of $\mathrm{ca} .1 \mathrm{~cm}$.

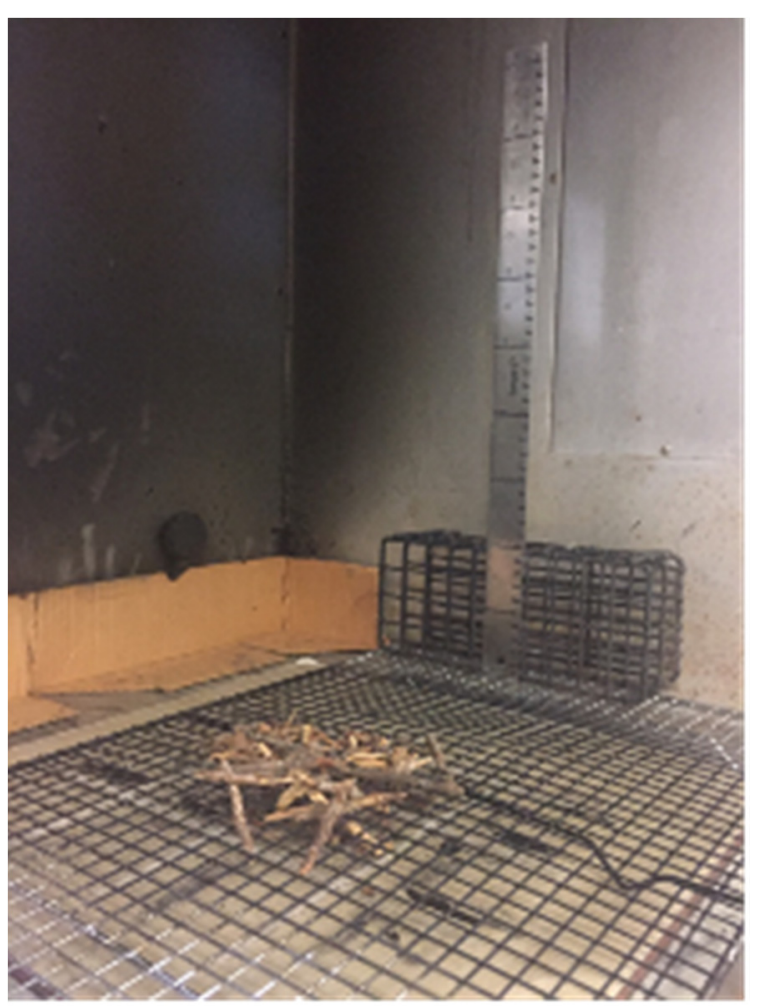

Figure 1. Flammability analysis of $0.00-0.63 \mathrm{~cm}$ pine FWD with fuel bed depth ca. $1 \mathrm{~cm}$. Six xylene soaked cotton strings were arranged in a grid $7.5 \mathrm{~cm}$ apart on the $35 \times 35 \mathrm{~cm}$ tile beneath a rack raised $2 \mathrm{~cm}$. Flammability trials were recorded with an iPad. A $55 \mathrm{~cm}$ ruler was mounted to be visible behind the flames.

Though a raised rack has not been used in previous flammability studies, practice burns revealed the use of the raised rack produced more even and complete burns. The raised rack also ensured more accurate measures of maximum flame heights (especially for fuels with low flame heights) by reducing the presence of flame heights produced by the ignited strings (ca. $10 \mathrm{~cm}$ ). Prepared fuel beds were ignited on the side of the cotton strings closest to the fume hood fan. In trial burns, this technique maximized potential differences for the rate of spread of the flames across the fuels because spread was inhibited by the fume hood fan. Each subsample ignition was video recorded with an iPad at a constant distance and angle to the fuel bed to measure resistance to ignition (s), maximum flame height (cm), flaming duration (s), and smoldering duration (s) (Figure 2). Additionally, a $55 \mathrm{~cm}$ ruler was visible behind the flames in the video frame. As burns progressed, we used hand signals 
to indicate fuel ignition, end of flaming, and end of smoldering because these critical moments were difficult to discern with the video alone. Resistance to ignition was measured as the time between the flames produced by the cotton strings reached the fuel to actual fuel ignition. Maximum flame height was measured by noting the highest reach of the flame against a ruler mounted behind the fuel bed. Flames that were greater than $60 \mathrm{~cm}$ exceeded the video frame and were estimated, then independently quality checked by multiple observers. This occurred with yellow jessamine vines and leaves, pine needles, bracken fern, FF oaks, and grass. Flaming duration was measured as the time between fuel ignition and end of flame. Smoldering duration was measured as the time between end of flame and end of visible smoke production. Additionally, residual ash (with unburned strings removed) was weighed for each burn to calculate percent consumption (\%) based on dry weight. Tiles were washed and cooled between each burn to ensure similar starting conditions for each subsample.

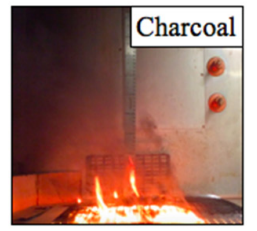

Low

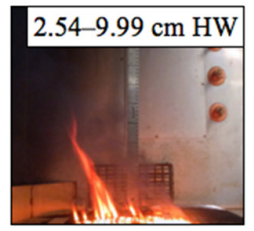

Mod-Low

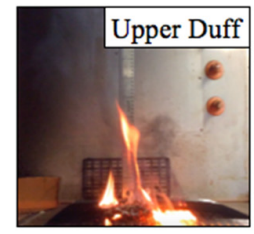

Mod

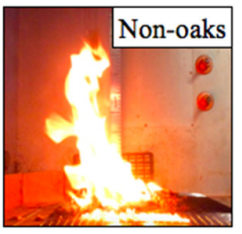

Mod-High

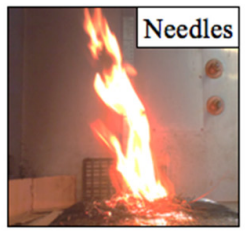

gh

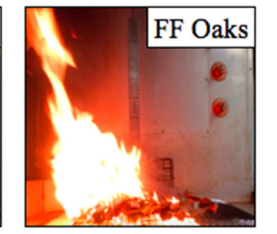

High

Figure 2. Still frames of burn recordings used to quantify flammability characteristics.

As fuels used for flammability analysis were at laboratory moisture conditions, we measured the moisture content of all fuels. All 21 categories that underwent flammability analysis were each prepared into a $15.0 \mathrm{~g}$ sample independent from the subsamples used in the flammability analysis. These independent samples were dried in an oven at $70{ }^{\circ} \mathrm{C}$ for $24 \mathrm{~h}$ [13]. Samples were removed from the oven and allowed to cool to room temperature, then weighed. Fuel weight differences before and after oven drying were used to calculate moisture content of the fuels. Moisture ranged from $4.0 \%-8.7 \%$ with a mean of $6.4 \% \pm 0.3$ standard errors $(\mathrm{SE})$.

\subsection{Analytical Methods}

We averaged the five subsamples of each fuel category because flammability characteristics of the fuel categories were not independent from each other. Flammability characteristics for the 21 fuel categories were tested for normality and independence, as flammability metrics are often noted for tight correlations. Standard errors (SE) were calculated for each fuel category and flammability characteristic. Averages for resistance to ignition, maximum flame height, flaming duration, smoldering duration, and percent consumption met conditions of linearity and independence. The only exception to this was a potential correlation between maximum flame height and percent consumption $\left(r^{2}=0.79\right)$. Based on irregularity of smoldering duration values obtained in this study, in addition to previous work where smoldering duration did not clarify fuel flammability [22,33] or was not included in flammability studies [29,53,54], we concluded smoldering duration values were not robust enough for clustering analysis. Though this approach may seem overly cautious, we attempted to carefully exclude any potential errors from flammability analysis because a wide range of fuels were analyzed in this study, and we instead relied on the other four, consistent flammability metrics for post-hoc clustering. We used PC-Ord v. 6 software to statistically cluster the fuels because the analysis was robust to non-comparable metrics (e.g., cm, s, and \%, [55]). Using Euclidean distance and Ward's method in PC-Ord, we hierarchically clustered fuel categories into groups of similar flammability characteristics. As this was an unsupervised learning technique, we selected the minimum number of flammability groups necessary to adequately describe variation in fuels.

We validated our group selection using a multi-response permutation procedure (MRPP) in PC-Ord to test for differences between flammability groups based on within-group similarities using the A statistic as a measure of chance-corrected within-group agreement. An $\mathrm{A}=0$ indicates the 
heterogeneity within groups equals that expected by chance, and an $\mathrm{A}=1$ indicates all items are identical within groups [55]. Though the MRPP may indicate if fuel categories were appropriately assigned to flammability groups, it does not provide information on how groups differed. Thus, we used individual one-way analysis of variances (ANOVAs) in $\mathrm{R}$ to test for significant differences between the flammability characteristics of each cluster, and subsequent TukeyHSD post-hoc tests when significant differences were found to detect pair-wise differences.

To create an estimate of the relative abundance of each fuel category, we summed weights of the fuels (including those not used in the flammability analysis) by treatment type and by overall collected mass. Fuels were divided into two groups based on whether the fuel was woody (e.g., bark, yellow jessamine vine, FWD) or leafy (e.g., pine needles, Ericaceae, bracken fern). Fuel weights were relativized by a woody or a leafy subtotal, as well as by a complete total including both. We did this to ensure the denser, woody fuel categories were not disproportionately represented.

\section{Results}

\subsection{Variability of Flammability Metrics}

Maximum flame heights exhibited minimal intra-category variability (Table 2). The largest average maximum flame height was produced by grass $(70 \mathrm{~cm} \pm 6 \mathrm{SE}$ ). Percent consumption values also showed minimal intra-category variability (Table 2). The fuel categories with the highest consumption were FF oaks $(89.5 \% \pm 1.8)$ and grass $(87.6 \% \pm 0.9)$. Resistance to ignition showed the least amount of intra-category variation (Table 2). The fuel category with the shortest average ignition time was pine needles $(2 \mathrm{~s} \pm 1)$. Considering that all fuels had similar moisture conditions for flammability analysis, these conservative differences between fuel ignitions were not surprising, but may be different for fuels at field moisture conditions. Flaming duration had the second largest range (212 s) and showed more intra-category variation (Table 2). Similarly, smoldering duration had the greatest range (489 s) and the greatest intra-category variation (Table 2).

\subsection{Clustering of Flammability Groups}

Through hierarchical cluster of flammability characteristics (excluding smoldering duration) we reduced the 21 fuel categories to five flammability groups (low, moderate-low, moderate, moderate-high, and high) that explained $89.45 \%$ of the data variability (Figure 3). We selected five flammability groups from the hierarchical clustering analysis, an unsupervised learning technique, to ensure clusters satisfactorily explained data variation ( $\geq 75 \%$ variance, [27]) and to minimize the number of meaningfully grouped clusters produced. General trends from low to high flammability groups include decreasing resistance to ignition, increasing maximum flame height, and increasing percent consumption (Figure 4). The longest flaming and smoldering durations occurred in the moderate flammability group.

The low flammability group included bark and charcoal (two categories, average percent consumption $=7 \% \pm 1$, Table 3 ). The moderate-low flammability group included lower duff, all three size classes of hardwood, the $0.00-0.63 \mathrm{~cm}$ pine and $0.63-2.54 \mathrm{~cm}$ pine, and pine RS (seven categories, average percent consumption $=37 \% \pm 1$ ). The moderate flammability group included wood fragments, upper duff, and $2.54-9.99 \mathrm{~cm}$ pine (three categories, average percent consumption $=49 \% \pm 6$ ). The moderate to moderate-high flammability groups reflect a change from predominantly woody (denser) to leafy (less dense) fuel types (see Table 4 for woody and leafy fuel divisions). The moderate-high flammability group included yellow jessamine vines and leaves, oak fragments, non-oaks, pine needles, and Ericaceae leaves (six categories, average percent consumption $=79 \% \pm 2$ ). The high flammability group included bracken fern, grass, and FF oak (three categories, average percent consumption $=86 \% \pm 1$ ). 


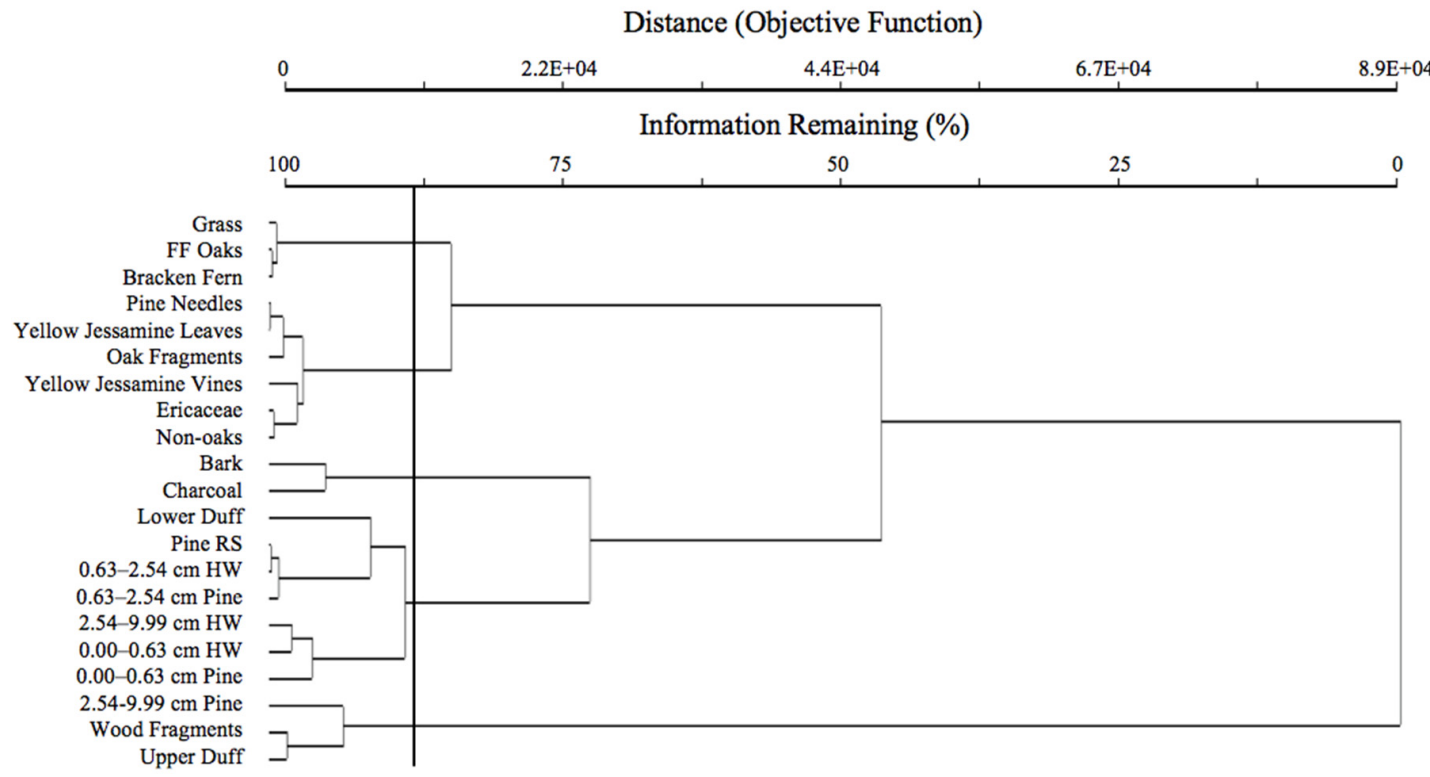

Figure 3. Hierarchical clustering of flammability characteristics. Vertical line marks five clusters explaining $89 \%$ of the variance.
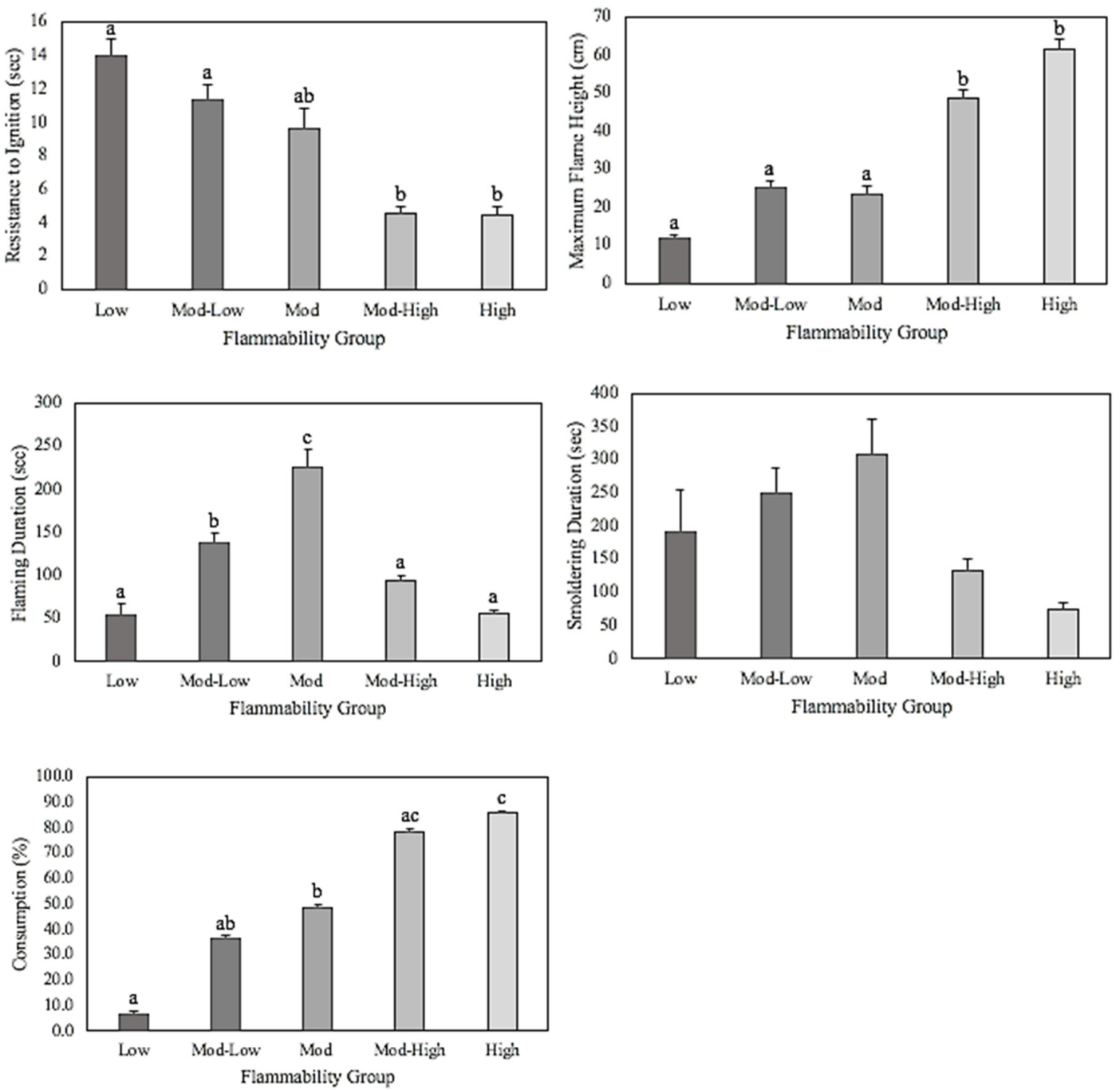

Figure 4. Group averages of flammability characteristics with standard error bars. Significance indicated by letters with $p<0.05$. 
Table 3. Averages and standard errors (SE) for flammability characteristics of flammability groups produced by statistical clustering.

\begin{tabular}{|c|c|c|c|c|c|c|}
\hline FG & Fuel Categories & RI (s) & MFH (cm) & FD (s) & SD (s) & $\mathrm{C}(\%)$ \\
\hline Low & Bark, Charcoal & $14 \pm 1$ & $12 \pm 1$ & $54 \pm 13$ & $192 \pm 63$ & $6.7 \pm 0.7$ \\
\hline Mod-Low & $\begin{array}{c}\text { Lower Duff, } 0.00-9.99 \mathrm{~cm} \mathrm{HW} \text {, } \\
0.00-2.54 \mathrm{~cm} \text { Pine, Pine RS }\end{array}$ & $11 \pm 1$ & $25 \pm 2$ & $138 \pm 11$ & $250 \pm 38$ & $36.7 \pm 4.7$ \\
\hline Mod & $\begin{array}{l}\text { Wood Fragments, Upper } \\
\text { Duff, 2.54-9.99 cm Pine } \\
\text { Yellow Jessamine, Oak }\end{array}$ & $10 \pm 1$ & $24 \pm 2$ & $225 \pm 21$ & $309 \pm 53$ & $48.8 \pm 5.6$ \\
\hline Mod-High & $\begin{array}{l}\text { Fragments, Non-oaks, } \\
\text { Ericaceae, Needles }\end{array}$ & $5 \pm 0$ & $49 \pm 2$ & $94 \pm 6$ & $134 \pm 16$ & $78.5 \pm 1.8$ \\
\hline High & Bracken Fern, Grass, FF Oaks & $4 \pm 1$ & $62 \pm 3$ & $57 \pm 3$ & $75 \pm 10$ & $86.0 \pm 1.4$ \\
\hline
\end{tabular}

Notes: Flammability characteristics include resistance to ignition (RI), maximum flame height (MFH), flaming duration (FD), smoldering duration (SD), and consumption (C). Other abbreviations include flammability group (FG), hardwood (HW), and reproductive structures (RS).

Table 4. Relativized weights of fuel categories by woody or leafy subtotals, and by total fuel collected.

\begin{tabular}{|c|c|c|c|c|}
\hline Fuel Category & Fuel Type & Total (g) & Rel. Woody/Leafy & Rel. Total \\
\hline Pine Needles & Leafy & 6465.9 & $0.4952(1)$ & 0.2042 \\
\hline Bark & Woody & 4898.7 & $0.2633(1)$ & 0.1547 \\
\hline $2.54-9.99 \mathrm{~cm}$ Pine & Woody & 3704.8 & $0.1992(2)$ & 0.1170 \\
\hline $0.63-2.54 \mathrm{~cm}$ Pine & Woody & 2640.1 & $0.1419(3)$ & 0.0834 \\
\hline $0.63-2.54 \mathrm{~cm} \mathrm{HW}$ & Woody & 2539.9 & $0.1365(4)$ & 0.0802 \\
\hline $2.54-9.99 \mathrm{~cm} \mathrm{HW}$ & Woody & 1640.2 & $0.0882(5)$ & 0.0518 \\
\hline Lower Duff & Leafy & 1352.6 & $0.1036(2)$ & 0.0427 \\
\hline Pine RS & Woody & 1160 & $0.0624(6)$ & 0.0366 \\
\hline Upper Duff & Leafy & 1148.4 & $0.0879(3)$ & 0.0363 \\
\hline Non-oaks & Leafy & 997.5 & $0.0764(4)$ & 0.0315 \\
\hline Yellow Jessamine Vines & Woody & 766.9 & $0.0412(7)$ & 0.0242 \\
\hline Grass & Leafy & 731.8 & $0.0560(5)$ & 0.0231 \\
\hline Fire-Facilitating Oaks & Leafy & 713.4 & $0.0546(6)$ & 0.0225 \\
\hline $0.00-0.63 \mathrm{~cm} \mathrm{HW}$ & Woody & 708.8 & $0.0381(8)$ & 0.0224 \\
\hline Bracken Fern & Leafy & 559.5 & $0.0428(7)$ & 0.0177 \\
\hline Oak Fragments & Leafy & 419.6 & $0.0321(8)$ & 0.0133 \\
\hline Ericaceae & Leafy & 323.7 & $0.0248(9)$ & 0.0102 \\
\hline Yellow Jessamine Leaves & Leafy & 243.4 & $0.0186(10)$ & 0.0077 \\
\hline Charcoal & Woody & 231.8 & $0.0125(9)$ & 0.0073 \\
\hline $0.00-0.63 \mathrm{~cm}$ Pine & Woody & 146 & $0.0078(10)$ & 0.0046 \\
\hline Wood Fragments & Woody & 145.9 & $0.0078(11)$ & 0.0046 \\
\hline Fire-Impeding Oaks & Leafy & 65.6 & $0.0050(11)$ & 0.0021 \\
\hline Moderate-Burning Oaks & Leafy & 19.6 & $0.0015(12)$ & 0.0006 \\
\hline Herbs & Leafy & 13.5 & $0.0010(13)$ & 0.0004 \\
\hline Herbaceous RS & Woody & 12.75 & $0.0007(12)$ & 0.0004 \\
\hline Hardwood RS & Woody & 7.2 & $0.0004(13)$ & 0.0002 \\
\hline Scat & Leafy & 2.9 & $0.0002(14)$ & 0.0001 \\
\hline Insects & Leafy & 0.9 & 0.0001 (15) & 0.0000 \\
\hline
\end{tabular}

Notes: Based on fuel type, fuels were relativized with a leafy $(13,058.3 \mathrm{~g})$ or woody subtotal $(18,603.1 \mathrm{~g}$; Rel. Woody/Leafy) with ranking shown in parentheses. Fuels were also relativized and sorted by total fuels (31,661.4 g; Rel. Total). Abbreviations include hardwood (HW) and reproductive structures (RS).

\subsection{Significance of Flammability Groups}

The MRPP confirmed fuel categories within flammability groups were relatively similar to each other $(\mathrm{A}=0.63)$ and were more similar to each other than different flammability groups $(p$ $<0.001$ ). Subsequent ANOVAs of flammability group characteristics proved significantly different (resistance to ignition, $p=0.001$, maximum flame height, flaming duration, and percent consumption, $p<0.001$ ) and were analyzed with TukeyHSD post-hoc tests (Table 3). Concerning resistance to ignition, 
low and moderate-low groups (predominantly woody) were significantly different from moderate-high and high groups (predominantly leafy, Figure 4). Maximum flame height showed a distinct divide between the woody and leafy flammability groups, where low, moderate-low, and moderate were not significantly different from each other, but all were significantly different from moderate-high and high. Flaming duration peaked with the moderate group, where low, moderate-high, and high groups were not significantly different from each other, but were significantly shorter than moderate-low, itself significantly shorter than moderate. Finally, percent consumption showed the least distinction between woody and leafy groups, as significant differences incrementally increased from low to high.

\subsection{Relative Abundance of Collected Fuel}

Using totals that included all treatments, the woody fuel in the greatest abundance was bark $(4898.7 \mathrm{~g})$ and the leafy fuel in the greatest abundance was pine needles (6465.9 $\mathrm{g}$, Table 4$)$. The two duff categories were ranked the next highest for the leafy fuels, with $1352.6 \mathrm{~g}$ and $1148.4 \mathrm{~g}$, respectively. Abundance of woody fuel tended to be greater for pines and increased with increasing size. Overall, totals from the nine sampled plots indicated that wind-disturbed plots had the most fuel $(12,491.6 \mathrm{~g})$ which was largely woody, closely followed by mature plots $(11,144.7 \mathrm{~g})$ which were largely leafy. Salvage-logged plots had the least amount of fuel $(8025.1 \mathrm{~g})$, with the majority classed as woody.

Leafy totals in mature plots were similar to overall abundance rankings, with pine needles the most abundant ( 0.5149 of leafy subtotal), followed by lower duff ( 0.0513 of leafy subtotal) and upper duff (0.0379 of leafy subtotal). Moreover, woody totals reflected a greater abundance of pine related fuels. Conversely, wind-disturbed plots showed a greater abundance of woody fuel as compared to leafy fuel. Wind-disturbed plots also showed an increase in the abundance of bracken fern. Salvage-logged plots showed an even greater abundance of woody fuel as compared to leafy, and the leafy fuel in the greatest abundance was grass.

\section{Discussion}

\subsection{Variability of Flammability Metrics}

Resistance to ignition showed the least variation across fuel categories (2-17 s) and did not greatly distinguish fuels in flammability groups. Given such minimal differences, we would not expect resistance to ignition of fuels to be an important limiting factor for fire behavior at these moisture conditions (ca. 6\% water content-a typical low moisture content in prescribed burns, [56]). Although in the field, fuels likely have increased fuel moisture that would impact ignition [54], particularly for mesophytic species or duff [13], potential pre-heating by approaching flames may dry fuels toward a balance between these studies and ignitability in this study.

The correlation between maximum flame height and percent consumption is often noted in the literature [3]. The low variability and wide range $(9-70 \mathrm{~cm})$ of maximum flame height for fuel categories indicated potential replicability and its strength as a metric for clustering. In general, maximum flame heights reported here were less than those reported in the literature, but this could be a result of different laboratory methods. In our study, FF oaks had a maximum flame height of $54 \mathrm{~cm} \pm 3$, compared to maximum flame heights of $80 \mathrm{~cm} \pm 2$ [33], and pine needles had a maximum flame height of $59 \mathrm{~cm} \pm 4$, compared to $82 \mathrm{~cm}$ for longleaf pine [35]. Yet despite these differences in maximum flame height, which we suspect was the result of comparing air-dried to oven-dried fuels or our use of a rack to elevate the fuel bed, percent consumption values tended to be similar for FF oaks $(90 \% \pm 2$ compared to $89 \% \pm 1$, [33]) and pine needles ( $81 \% \pm 2$ compared to $92 \%$, [35]). The greatest flame height produced in this study was grass $(70 \mathrm{~cm} \pm 6)$. Even though the most abundant grass species on our site was little bluestem, the bunchgrass species may not be as important to fire behavior as the structural combination of fuel perching and the vertical reach of grasses. For instance, Wenk et al. [12] observed this same structural combination between wiregrass and turkey oak, and further found these fuel complexes met objectives of hardwood control and reduced fuel loads. As a result, we would 
also expect to meet similar fire management objectives with bunchgrass, FF oaks, and pine needles on this site.

Observed flaming and smoldering durations in laboratory burns may be the least translatable to actual fire behavior because of fuel interactions. For example, the increased oxygen flow resulting from pine needle perching [1,57] illustrates an important difference between how pine needles burn in the field as compared to even packing in laboratory burns. However, we do not expect the interaction between grass and pines needles would cause significant departures from laboratory estimated percent consumption values because both grass and pine needles already experienced high percent consumption individually, and pine needles were most abundant on mature sites, whereas grass was most abundant on salvage-logged sites.

Incorporating the longest average flaming duration category, the upper duff, with pinecone ignition, is an important interaction laboratory burns eliminate. Though the percent consumption values of the lower and upper duff were only $9 \% \pm 1$ and $47 \% \pm 7$, the addition of pine cones would likely increase the amount of duff consumed [58], expose more bare mineral soil, and improve longleaf pine seed germination [21]. Similarly, the likely underestimated smoldering duration of duff without facilitated ignition from pinecones presented here may have important consequences for soil heating and plant mortality. Although our study site likely did not have levels of duff accumulation that would negatively affect mature longleaf pine trees, duff abundance may be substantial enough to cause seedling and sapling mortality [12] or decreased herb resprouting [15].

\subsection{Clustering of Flammability Groups}

Clustering fuels of longleaf pine woodlands by their flammability characteristics explained previously unknown fuel similarities. For example, maximum flame heights of bracken fern $(61 \mathrm{~cm} \pm 3)$ and yellow jessamine vines $(57 \mathrm{~cm} \pm 4)$ and leaves $(53 \mathrm{~cm} \pm 4)$ indicated that these previously unstudied fuels would burn similarly to FF oaks and pine needles, further supported by clustering analysis. Since Skutch [59], bracken fern has been noted to increase in abundance following disturbance, and indeed Kleinman et al. [46] observed a high abundance of bracken fern following catastrophic wind disturbance. Furthermore, Spencer and Baxter [60] discussed how after fires, bracken ferns (Pteridium spp.) rapidly regenerate from below-ground rhizomes, though abundance eventually declines as other species gain dominance. These results support our hypothesis that herbaceous species, such as bracken fern and yellow jessamine, may aid longleaf pine regeneration by producing moderate severity fires similar to those of a self-maintained longleaf pine woodland [2], despite lacking a pine needle fuel bed $[14,36]$. We speculate that although herbaceous species diversity may decline as a result of the greater post-fire dominance of bracken fern [10], the flammability characteristics of bracken fern may produce more effective prescribed fires to aid longleaf pine regeneration. An important caveat is that although bracken fern and yellow jessamine burn similarly to pine needles, they rarely occur in the concentrated masses that were used in our flammability analysis (i.e. $15.0 \mathrm{~g}$ packed in a volume of $1 \times 35 \times 35 \mathrm{~cm})$.

Although we expected pine needles to cluster into the high flammability group based on our observed maximum flame height and laboratory burns by Fonda [35], they were instead grouped into the moderate-high flammability group. This may in part reflect the questionable ability of laboratory burns to accurately capture flammability [3], but more likely is a result of using unsupervised learning to form clusters. Specifically, this grouping was likely influenced by its relatively long flaming duration as compared to bracken fern, grass, and FF oaks. Similarly, we were surprised non-oaks were sorted in the moderate-high flammability group with pine needles (Table 3). Leaf litter produced by non-oak species such as red maple has been implicated as a mechanism driving mesophication in oak dominated systems [9], however, this category exemplified unexpectedly high flames and percent consumption (Table 2). These high flammability metrics were likely confounded by the presence of other leaf types of unknown flammability characteristics (e.g., muscadine and black gum) or contributions of American beech, which burn similar to FF oaks [30]. 
Alternatively, these discrepancies may be a product of burning leaves that had been at laboratory moisture conditions before ignition. In a study on differential litter drying rates, Kreye et al. [13] found mesophytic species such as red maple, water oak, and American beech had higher initial moisture levels and dried slower than pyrophytic species such as longleaf pine, turkey oak, and southern red oak. Moreover, the study found drying rates for broadleaves were best explained by leaf curl, an important structural trait Engber and Varner [27] linked to leaf flammability, while Nelson and Heirs [57] showed fuel bed properties such as fuel loading and arrangement were the main determinants for longleaf pine litter drying rates. In our study, red maple leaves were often curled, which may partly explain why the non-oak fuel category was clustered as high as it was. Additionally, Kleinman et al. [46] found relatively high stem density of red maple saplings on mature plots (19\% of all saplings), compared to a limited density of Florida maple (Acer floridanum (Chapm.) Pax) and sugar maple (Acer saccharum, Marsh.) saplings on wind-disturbed plots. Though maple species are broadly considered mesophytic, there may be interspecific differences in leaf curl, moisture retention, and flammability characteristics such as those exemplified in oak and pine species that may explain this apparent high flammability of non-oaks [25,33]. As this was the first instance of even indirectly measuring the flammability characteristics of maple leaves in a laboratory burn, future research may consider species specific flammability analyses of the non-oak category studied here.

\subsection{Significance of Flammability Groups}

The MRPP, subsequent ANOVAs, and TukeyHSD post-hoc tests justified our selected clustering of these fuel categories into five flammability groups that satisfactorily explained data variance [27]. However, these clusters were based on individual category response in a controlled environment, and as discussed, interactions between fuels will be an important consideration moving forward [3]. Generally, the low and moderate-low clusters (mostly woody) were significantly different from moderate clusters, which were significantly different from moderate-high and high clusters (mostly leafy) for percent consumption, resistance to ignition, and maximum flame height (Figure 4). Similar trends were observed in the three distinct fuel groups of ravine and upland tree species leaves produced by Mola et al. [30], with short flames, minimal fuel consumption (ca. 40\%), and high moisture retention on one extreme, compared to high flames, substantial fuel consumption (ca. 90\%), and rapidly lost moisture on the other.

As our study included fuels other than leaves, flammability characteristics tended to noticeably divide between leafy and woody fuels, with flammability extremes spread across a larger gradient than those observed by Mola et al. [33]. As one intended outcome of producing flammability groups was to aid future comparisons between laboratory and field burns, we recommend percent consumption as a suitable basis for comparison. For instance, though fire behavior is difficult to quantify, percent consumption, which is largely controlled by fire behavior [16] and correlated with fire intensity [27], could readily be calculated from pre- and post-fire fuel loadings.

\section{Conclusions}

Through controlled laboratory burns, we were able to condense the wide range of available surface fuels, including many unstudied fuels, in a longleaf pine woodland to five flammability groups. Fuels in these groups share similar resistance to ignition, flaming duration, maximum flame height, and percent consumption values. The establishment of these groups should facilitate quantification of the fuel bed by researchers and managers on sites with similar plant communities and provide a model for other frequent-fire forest types. Notably, we found that some herbaceous species actually burn similarly to pine needles, which are considered the primary driver of fire in longleaf pine stands. Thus, after catastrophic disturbance in longleaf pine ecosystems, an increase in high flammability herbaceous species may maintain fire-vegetation feedbacks and promote recovery to longleaf pine dominance [26], but additional research is needed. 
We recommend further laboratory burns should attempt to incorporate possible interactions between Ericaceae spp. or bracken fern and pine needles, with potential interactions further explored by substituting a fuel from an expected interaction with a fuel clustered to burn similarly. Fo example, yellow jessamine vines could be substituted for Ericaceae spp. interactions with pine needles. Additionally, it may be important to combine low, moderate, and high burning fuels in laboratory burns to confirm that fuels clustered to have comparable flammability characteristics still burn similarly when allowed to interact. Finally, and perhaps most importantly, further research should be conducted in applying laboratory results to fire behavior in the field as an important step to uniting theory and practice in prescribed fire science.

Author Contributions: R.K.E. conceived and designed the study, collected data and analyzed data, and wrote the original manuscript draft. J.L.H. conceived and designed the study and edited the manuscript. All authors have read and agreed to the published version of the manuscript.

Funding: This research was funded in part by the USDA Forest Service, Talladega National Forest, Oakmulgee Ranger District.

Acknowledgments: We thank the USDA Forest Service, Talladega National Forest, Oakmulgee Ranger District staff for funding and logistical support. We thank Jonathan Kleinman, Piper Stone, Lydia Blount, Tyler Mathews, Kevin Willson, and Scott Ford for assistance with field data collection and Allan White, Andy O'Shields, Lee Casals, Kevin Convington, and Donovan Murphy for assistance in the laboratory. We thank Morgan Varner for advice and recommendations on our methods, and we thank Jonathan Kleinman, Davis Goode, and anonymous reviewers for helpful comments on earlier drafts of the manuscript.

Conflicts of Interest: The authors declare no conflict of interest.

\section{References}

1. Mitchell, R.J.; Hiers, J.K.; O’Brien, J.; Starr, G. Ecological Forestry in the Southeast: Understanding the Ecology of Fuels. J. For. 2009, 107, 391-397.

2. Fill, J.M.; Platt, W.J.; Welch, S.M.; Waldron, J.L.; Mousseau, T.A. Updating Models for Restoration and Management of Fiery Ecosystems. For. Ecol. Manag. 2015, 356, 54-63. [CrossRef]

3. Varner, J.M.; Kane, J.M.; Kreye, J.K.; Engber, E.A. The Flammability of Forest and Woodland Litter: A Synthesis. Curr. For. Rep. 2015, 1, 91-99. [CrossRef]

4. Anderson, H.E. Forest Fuel Ignitability. Fire Technol. 1970, 6, 312-319. [CrossRef]

5. Martin, R.E.; Gorden, D.A.; Gutierrez, M.E.; Lee, D.S.; Molina, D.M.; Schroeder, R.A.; Sapsis, D.A.; Stephens, S.L.; Chambers, M. Assessing the Flammability of Domestic and Wildland Vegetation. In Proceedings of the 12th Conference on Fire and Forest Meteorology, Jekyll Island, GA, USA, 26-28 October 1993; Society of American Foresters Publication 94-02; Bethesda: Rockville, MD, USA, 1993; pp. 130-137.

6. Loudermilk, E.L.; Cropper, W.P.; Mitchell, R.J.; Lee, H. Longleaf Pine (Pinus palustris) and Hardwood Dynamics in a Fire-Maintained Ecosystem: A Simulation Approach. Ecol. Model. 2011, 222, 2733-2750. [CrossRef]

7. Wahlenberg, W.G. Longleaf Pine: Its Use, Ecology, Regeneration, Protection, Growth, and Management; Charles Lathrop Pack Forest Foundation: Washington, DC, USA, 1946.

8. Frost, C.C. History and Future of the Longleaf Pine Ecosystem. In The Longleaf Pine Ecosystem, Ecology, Silviculture, and Restoration; Jose, S., Jokela, E.J., Miller, D.L., Eds.; Springer: New York, NY, USA, 2006; pp. 9-48.

9. Nowacki, G.J.; Abrams, M.D. The Demise of Fire and "Mesophication" of Forests in the Eastern United States. Bioscience 2008, 58, 123-138. [CrossRef]

10. Glitzenstein, J.S.; Streng, D.R.; Wade, D.D. Fire Frequency Effects on Longleaf Pine (Pinus palustris P. Miller) Vegetation in South Carolina and Northeast Florida, USA. Nat. Areas J. 2003, 23, 22-37.

11. Boring, L.R.; Hendricks, J.J.; Wilson, C.A.; Mitchell, R.J. Season of Burn and Nutrient Losses in a Longleaf Pine Ecosystem. Int. J. Wildland Fire 2004, 13, 443-453. [CrossRef]

12. Wenk, E.S.; Wang, G.G.; Walker, J.L. Within-Stand Variation in Understory Vegetation Affects Fire Behavior in Longleaf Pine Xeric Sandhills. Int. J. Wildland Fire 2011, 20, 866-875. [CrossRef] 
13. Kreye, J.K.; Varner, J.M.; Hiers, J.K.; Mola, J. Toward a Mechanism for Eastern North American Forest Mesophication: Differential Litter Drying across 17 Species. Ecol. Appl. 2013, 23, 1976-1986. [CrossRef]

14. Wiggers, M.S.; Kirkman, L.K.; Boyd, R.S.; Hiers, J.K. Fine-Scale Variation in Surface Fire Environment and Legume Germination in the Longleaf Pine Ecosystem. For. Ecol. Manag. 2013, 310, 54-63. [CrossRef]

15. Gagnon, P.R.; Passmore, H.A.; Slocum, M.; Myers, J.A.; Harms, K.E.; Platt, W.J.; Paine, C.E.T. Fuels and Fires Influence Vegetation Via Above- and Belowground Pathways in a High-Diversity Plant Community. J. Ecol. 2015, 103, 1009-1019. [CrossRef]

16. O’Brien, J.J.; Loudermilk, E.L.; Hiers, J.K.; Pokswinski, S.M.; Hornsby, B.; Hudak, A.T.; Strother, D.; Rowell, E.; Bright, B.C. Canopy-Derived Fuels Drive Patterns of In-Fire Energy Release and Understory Plant Mortality in a Longleaf Pine (Pinus palustris) Sandhill in Northwest Florida, USA. Can. J. Remote Sens. 2016, 42, 489-500. [CrossRef]

17. Varner, J.M.; Kush, J.S.; Meldahl, R.S. Structural Characteristics of Frequently-Burned Old-Growth Longleaf Pine Stands in the Mountains of Alabama. Castanea 2003, 68, 211-221.

18. Cipollini, M.L.; Culberson, J.; Strippelhoff, C.; Baldvins, T.; Miller, K. Herbaceous Plants and Grasses in a Mountain Longleaf Pine Forest Undergoing Restoration: A Survey and Comparative Study. Southeast. Nat. 2012, 11, 637-668. [CrossRef]

19. Stambaugh, M.C.; Varner, J.M.; Jackson, S.T. Biogeography: An Interweave of Climate, Fire, and Humans. In Ecological Restoration and Management of Longleaf Pine Forests; Kirkman, K., Jack, S., Eds.; CRC Press: Boca Raton, FL, USA, 2017; pp. 17-38.

20. Buma, B.; Wessman, C.A. Disturbance Interactions can Impact Resilience Mechanisms of Forests. Ecosphere 2011, 2, 1-13. [CrossRef]

21. Mitchell, R.J.; Hiers, J.L.; O’Brien, J.J.; Jack, S.B.; Engstrom, R.T. Silviculture that Sustains: The Nexus between Silviculture, Frequent Prescribed Fire, and Conservation of Biodiversity in Longleaf Pine Forests of the Southeastern United States. Can. J. For. Res. 2006, 36, 2713-2723. [CrossRef]

22. Varner, J.M.; Kane, J.M.; Banwell, E.M.; Kreye, J.K. Flammability of Litter from Southeastern Trees: A Preliminary Assessment. In Proceedings of the 17th Biennial Southern Silvicultural Research Conference; Holley, A.G., Connor, K.F., Haywood, J.D., Eds.; Department of Agriculture Forest Service; Southern Research Station: Asheville, NC, USA, 2015; pp. 183-187.

23. Rothermel, R.C. A mathematical Model for Predicting Fire Spread in Wildland Fuels; Res. Pap. INT-115; Department of Agriculture; Intermountain Forest and Range Experiment Station: Ogden, UT, USA, 1972; p. 40.

24. Kreye, J.K.; Varner, J.M.; Hamby, G.W.; Kane, J.K. Mesophytic Litter Dampens Flammability in Fire-Excluded Pyrophytic Oak-Hickory Woodlands. Ecosphere 2018, 9. [CrossRef]

25. Bale, A.M. Fire Effects and Litter Accumulation Dynamics in a Montane Longleaf Pine Ecosystem. Master's Thesis, University of Missouri, Columbia, MO, USA, 2009.

26. Kleinman, J.S.; Goode, J.D.; Hart, J.L.; Dey, D.C. Prescribed Fire Effects on Pinus palustris Woodland Development after Catastrophic Wind Disturbance and Salvage Logging. For. Ecol. Manag. 2020, 468, 118173. [CrossRef]

27. Engber, E.A.; Varner, J.M. Patterns of Flammability of the California Oaks: The Role of Leaf Traits. Can. J. For. Res. 2012, 42, 1965-1975. [CrossRef]

28. Ottmar, R.D.; Hudak, A.T.; Prichard, S.J.; Wright, C.S.; Restaino, J.C.; Kennedy, M.C.; Vihnanek, R.E. Pre-Fire and Post-Fire Surface Fuel and Cover Measurements Collected in the Southeastern United States for Model Evaluation and Development-RxCADRE 2008, 2011 and 2012. Int. J. Wildland Fire 2016, 25, 10-24. [CrossRef]

29. Ganteaume, A.; Jappiot, M.; Curt, T.; Lampin, C.; Borgniet, L. Flammability of Litter Sampled According to two Different Methods: Comparison of Results in Laboratory Experiments. Int. J. Wildland Fire 2014, 23, 1061-1075. [CrossRef]

30. Mola, J.M.; Varner, J.M.; Jules, E.S.; Spector, T. Altered Community Flammability in Florida's Apalachicola Ravines and Implications for the Persistence of the Endangered Conifer Torreya Taxifolia. PLoS ONE 2014, 9, e103933. [CrossRef] [PubMed]

31. Zhao, W.; van Logtestijn, R.S.P.; van der Werf, G.R.; van Hal, J.R.; Cornelissen, J.H.C. Disentangling Effects of Key Coarse Woody Debris Fuel Properties on its Combustion, Consumption and Carbon Gas Emissions during Experimental Laboratory Fire. For. Ecol. Manag. 2018, 427, 275-288. [CrossRef]

32. Varner, J.M.; Kane, J.M.; Hiers, J.K.; Kreye, J.K.; Veldman, J.W. Suites of Fire-Adapted Traits of Oaks in the Southeastern USA: Multiple Strategies for Persistence. Fire Ecol. 2016, 12, 48-64. [CrossRef] 
33. Kane, J.M.; Varner, J.M.; Hiers, J.K. The Burning Characteristics of Southeastern Oaks: Discriminating Fire Facilitators from Fire Impeders. For. Ecol. Manag. 2008, 256, 2039-2045. [CrossRef]

34. Fonda, R.W.; Varner, J.M. Burning Characteristics of Cones from Eight Pine Species. Northwest Sci. 2004, 78, 322-333.

35. Fonda, R.W. Burning Characteristics of Needles from Eight Pine Species. For. Sci. 2001, 47, 390-396.

36. Kirkman, L.K.; Mitchell, R.J.; Kaeser, M.J.; Pecot, S.D.; Coffey, K.L. The Perpetual Forest: Using Undesirable Species to Bridge Restoration. J. Appl. Ecol. 2007, 44, 604-614. [CrossRef]

37. Gensini, V.A.; Brooks, H.E. Spatial Trends in United States Tornado Frequency. NPJ Clim. Atmos. Sci. 2018, 1, 1-5. [CrossRef]

38. Fenneman, N.M. Physiography of Eastern United States; McGraw-Hill: New York, NY, USA, 1938.

39. USDA NRCS (Natural Resources Conservation Service). Soil Survey of Bibb County, Alabama, 2008. Available online: http://soils.usda.gov/survey/printed_surveys/ (accessed on 9 September 2019).

40. Beckett, S.; Golden, M.S. Forest Vegetation and Vascular Flora of Reed Brake Research Natural Area, Alabama. Castanea 1982, 47, 368-392.

41. Thornthwaite, C.W. An Approach toward Rational Classification of Climate. Geogr. Rev. 1948, 38, 55-94. [CrossRef]

42. PRISM Climate Group. Data Explorer: Time Series Values for Individual Locations. 2019. Available online: http://prism.oregonstate.edu/explorer/ (accessed on 11 February 2019).

43. Shankman, D.; Hart, J.L. The Fall Line: A Physiographic-Forest Vegetation Boundary. Geogr. Rev. 2007, 97, 502-519. [CrossRef]

44. Peet, R.K. Ecological Classification of Longleaf Pine Woodlands. In The Longleaf Pine Ecosystem: Ecology, Silviculture, and Restoration; Jose, S., Jokela, E.J., Miller, D.L., Eds.; Springer: New York, NY, USA, 2006; pp. 51-93.

45. Kleinman, J.S.; Hart, J.L. Vascular Flora of Longleaf Pine Woodlands after Wind Disturbance and Salvage Harvesting in the Alabama Fall Line Hills. Castanea 2018, 83, 183-195. [CrossRef]

46. Kleinman, J.S.; Ford, S.A.; Hart, J.L. Catastrophic Wind and Salvage Harvesting Effects on Woodland Plants. For. Ecol. Manag. 2017, 403, 112-125. [CrossRef]

47. NOAA. National Climatic Data Center: Storms Events Database. 2019. Available online: https://www.ncdc. noaa.gov/stormevents/eventdetails.jsp?id=314799 (accessed on 9 September 2019).

48. Ragland, C. 2011 Tornado Damage —Cow Pen E Friendship Salvage; Invitation to Review; USDA Forest Service; Talladega National Forest: Brent, AL, USA, 2011; p. 10.

49. Ford, S.A.; Kleinman, J.S.; Hart, J.L. Effects of Wind Disturbance and Salvage Harvesting on Macrofungal Communities in a Pinus Woodland. For. Ecol. Manag. 2018, 407, 31-46. [CrossRef]

50. Soil Survey Staff. Keys to Soil Taxonomy, 10th ed.; Department of Agriculture Natural Resource Conservation Service: Washington, DC, USA, 2006.

51. Brown, J.K. Handbook for Inventorying Downed Woody Material; Intermountain Forest and Range Experiment Station; USDA Forest Service: Ogden, UT, USA, 1974.

52. NatureServe. NatureServe Explorer: An Online Encyclopedia of Life. 2019. Available online: http://explorer. natureserve.org/servlet/NatureServe?searchCommunityUid=ELEMENT_GLOBAL.2.685027 (accessed on 11 September 2019).

53. Scarff, F.R.; Westoby, M. Leaf Litter Flammability in Some Semi-Arid Australian Woodlands. Funct. Ecol. 2006, 20, 745-752. [CrossRef]

54. Page, W.G.; Jenkins, M.J.; Runyon, J.B. Mountain Pine Beetle Attack Alters the Chemistry and Flammability of Lodgepole Pine Foliage. Can. J. For. Res. 2012, 42, 1631-1647. [CrossRef]

55. McCune, B.; Mefford, M.J. PC-ORD Version 6: Multivariate Analysis of Ecological Data; MjM Software Design: Gleneden Beach, OR, USA, 2011.

56. Wade, D.D.; Lunsford, J.D. A Guide for Prescribed Fire in Southern Forests; United States Department of Agriculture Forest Service: Washington, DC, USA, 1989; pp. 13-18.

57. Nelson, R.M.; Hiers, J.K. The Influence of Fuelbed Properties on Moisture Drying Rates and Time Lags of Longleaf Pine Litter. Can. J. For. Res. 2008, 38, 2394-2404. [CrossRef]

58. Kreye, J.K.; Varner, J.M.; Dugaw, C.J.; Cao, J.; Szecsei, J.; Engber, E.A. Pine Cones Facilitate Ignition of Forest Floor Duff. Can. J. For. Res. 2013, 43, 512-516. [CrossRef] 
59. Skutch, A.F. Early Stages of Plant Succession Following Forest Fires. Ecology 1929, 10, 177-190. [CrossRef]

60. Spencer, R.J.; Baxter, G.S. Effects of Fire on the Structure and Composition of Open Eucalypt Forests. Austral. Ecol. 2006, 31, 638-646. [CrossRef] 